\title{
Prevalence and genotyping of Chlamydia trachomatis in symptomatic male patients from Istanbul, Turkey
}

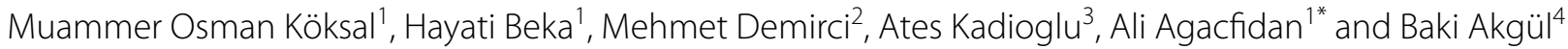

\begin{abstract}
This study was conducted to determine the prevalence and distribution of urogenital Chlamydia trachomatis genotypes in symptomatic male patients who were referred to the clinics of the Istanbul Faculty of Medicine. Of 419 urogenital swabs, 57 samples (13.6\%) were positive for C. trachomatis. Genotype distribution of C. trachomatis-positive samples identified five genetic variants namely genotype $E$ as the most prevalent ( $36.4 \%)$, followed by genotype $G$ $(23.6 \%), H(21.8 \%), D(16.4 \%)$ and $F(1.8 \%)$. We believe that this is the first study on distribution of genotypes of $C$. trachomatis genital infections in symptomatic men in Istanbul, Turkey.
\end{abstract}

Keywords: Chlamydia trachomatis, Epidemiology, Genotype distribution

\section{Background}

Chlamydia trachomatis (C. trachomatis) is an obligate intracellular bacterial pathogen, which continues to be the most commonly reported sexually transmitted bacterial infection and causes substantial morbidity and economic loss worldwide (WHO 2008). In 2008, the World Health Organization forecasted 106 million new urogenital chlamydia cases annually among the adult population globally. Compared to the majority of sexually transmitted infections (STIs), C. trachomatis infection is still the most frequently reported STI with 384.555 cases of $C$. trachomatis infection recorded in EU countries in 2013 (ECDC 2015). The prevalence of different serovars are indicators of the circulating $C$. trachomatis serovars in different geographical locations (Lysen et al. 2004). The connection between urogenital serovars and clinical manifestations is still inconclusive. While a direct correlation between clinical symptoms and certain serovars was found in some studies (Morre et al. 2000), no association was found between urogenital infections and serovars in others (Lysen et al. 2004). Currently, there

\footnotetext{
*Correspondence: ali.agacfidan@istanbul.edu.tr

${ }^{1}$ Department of Medical Microbiology, Istanbul Faculty of Medicine,

Istanbul University, Capa, 34093 Istanbul, Turkey

Full list of author information is available at the end of the article
}

are 19 identified human serovars and related variants (A, B/Ba, C, D/Da, E, F, G, Ga, H, I/Ia, J, K, L1, L2, L2a and L3) which are classified based on the antigenic variations of the major outer membrane protein (MOMP) (Morre et al. 2000). C. trachomatis serovars A, B/Ba and $C$ cause conjunctival infections and are related with ocular disease. Serotypes D/Da, E, F, G, Ga, H, I/Ia, J, K cause urogenital infections, and serovars L1, L2 and L3 are responsible for lymphogranuloma venereum (LGV) (Manavi 2006). The distribution of C. trachomatis genotypes have been identified in several countries of the world (Lysen et al. 2004; Taheri Beni et al. 2010; Millman et al. 2004; Ngandjio et al. 2003; Gallo Vaulet et al. 2010; Yang et al. 2010) and being predominant with the genotype E (26-46 \%), D (9-20 \%) and F (14-24 \%) in urogenital infections. Another study, in which samples were collected from countries in different geographical locations showed that C. trachomatis E (45\%), F (16\%), D $(13 \%), \mathrm{G}(10 \%)$ and $\mathrm{K}(\% 5,8)$ genotypes were reported as the most frequently detected genotypes in heterosexual patients (Herrmann et al. 2015).

A high resolution melting analysis (HRMA) method for cervical and urethral swabs has recently been developed for genotyping of the omp1 gene, which encodes MOMP (Li et al. 2010). 
The prevalence of genital chlamydial infection in symtomatic men in different regions of Turkey was reported in few studies and varied between 10.5 and $23 \%$ and was found to be at rates comparable to those of European countries (Agacfidan et al. 2001; Aslan et al. 2002; Kaleli et al. 1999). But so far, no data exists on the circulating genotype distribution in Turkey. The aim of this study was to determine and characterize the prevalence of $C$. trachomatis genotypes on symptomatic male patients attending a STD clinic in Istanbul University Faculty of Medicine by HRMA and sanger sequencing.

\section{Methods}

\section{Patients}

A total of 419 urogenital swab specimen were collected from male patients (aged 18-68) with symptoms (discharge, pain during urination, genito-urinary pain during sexual intercourse) for the investigation of STDs. Written informed consent for participation in this study was obtained from all participants. The authors assert that all procedures contributing to this work were approved by the Ethics Committee of Istanbul University (reference number 2015/1244), comply with the ethical standards on human experimentation and with the Helsinki Declaration of 1975, as revised in 2008. The swabs were placed in medium for Chlamydia PCR and were stored at $4{ }^{\circ} \mathrm{C}$ until transportation to the laboratory and then stored at $-20^{\circ} \mathrm{C}$ until real time PCR for C. trachomatis DNA was performed.

\section{Real time PCR analysis of C.trachomatis DNA}

DNA was prepared from urogenital samples using high pure PCR template preparation kit (Roche Diagnostics $\mathrm{GmBH}$, Mannheim Germany) and suspended in $200 \mu \mathrm{l}$ elution buffer according to the manufacturer's protocols (Morre et al. 1998).After quantification of isolated DNA, probes were studied according to the manufacturer's instructions on Light Cycler 2.0 (Roche Diagnostics $\mathrm{GmBH}$, Mannheim Germany) instrument. The master mix for C. trachomatis DNA real time PCR reactions were prepared using LightCycler ${ }^{\circledR}$ Fast Start DNA Master HybProbe kit (Roche Diagnostics GmBH, Mannheim, Germany) and Lightmix C. trachomatis kit (TIB Molbiol GmBH, Berlin, Germany). $5 \mu$ l of template DNA were added to each capillary tube for a final reaction volume of $20 \mu \mathrm{l}$. One negative and one positive control were included in each run. The PCR profile was an initial denaturation of template and activation of enzyme at $95^{\circ} \mathrm{C}$ for $10 \mathrm{~min}$ followed by 50 cycles of $95{ }^{\circ} \mathrm{C}$ for $5 \mathrm{~s}, 62^{\circ} \mathrm{C}$ for $5 \mathrm{~s}$, and $72{ }^{\circ} \mathrm{C}$ for $15 \mathrm{~s}$. Data analysis was performed as described in the LightCycler instrument operator's manual. The criteria used for determining positive and negative samples depended on the amplification curves at a wavelength of $640 \mathrm{~nm}$. C.trachomatis positive DNAs and samples were stored at $-70{ }^{\circ} \mathrm{C}$ for further analysis.

\section{HRM analysis}

The external primers for the VS1-VS2 PCR were CT1: 5'-TGA ACC AAG CCT TAT GAT CGA CGG A- $3^{\prime}$ and CT2: 5'-CGG AAT TGT GCA TTT ACG TGA G-3'. The internal PCR primers were selected as previously described by Zheng et al. (2007) and were CT3: 5'-ACT TTG TTT TCG ACC GTG TTT TG-3' and CT4: $5^{\prime}$-GAT TGA GCG TATTGG AAA GAA GC-3'. All primers were synthesized from IDT (Integrated DNA Technologies, Coraville, Iowa). C.trachomatis positive DNA samples were amplified in 96-well plates. LightCycler 480 High Resolution Master kit (Roche Diagnostics GmBH, Mannheim Germany) was used for HRM analysis in a LightCycler 480 II system (Roche Diagnostics GmBH, Mannheim Germany). In brief, each reaction was performed in a final volume of $10 \mu \mathrm{l}$ containing $20 \mathrm{ng}$ of DNA, $0.25 \mathrm{mM}$ of each primer (forward or reverse) and $1 \times$ LightCycler 480 HRM Master mix (Roche). The PCR profile was: an initial denaturation of template and activation of enzyme at $95^{\circ} \mathrm{C}$ for $10 \mathrm{~min}$ followed by 40 cycles of $95^{\circ} \mathrm{C}$ for $10 \mathrm{~s}, 57^{\circ} \mathrm{C}$ for $10 \mathrm{~s}$, and $72{ }^{\circ} \mathrm{C}$ for $20 \mathrm{~s}$. At the end of the PCR cycles, PCR products were denatured at $95^{\circ} \mathrm{C}$ for $1 \mathrm{~min}$ and rapidly cooled to $40^{\circ} \mathrm{C}$. HRM analyses were performed from $72{ }^{\circ} \mathrm{C}$ to $95{ }^{\circ} \mathrm{C}$ at a temperature gradient of $1{ }^{\circ} \mathrm{C} / \mathrm{sec}$, acquiring 25 data points per ${ }^{\circ} \mathrm{C}$. Each sample was run in duplicate for analysis. All samples were grouped by the LightCycler 480 Gene Scanning Software.

\section{Sequencing of the omp 1 gene}

DNA from C. trachomatis-positive samples was purified using the Qiaquick PCR Purification Kit (Qiagen, Hilden, Germany) as instructed by the manufacturer. The omp 1 gene was sequenced using the Big Dye Sequencing Terminator Kit and ABI $3130 \times 1$ sequencing system (Applied Biosystems, Foster City, CA, USA) with HRMA VS-1 and VS-2 primers. The strains with corresponding accession numbers B/IU-1226 (AF063208), B/B-16 (AY950630), D/B-120 (X62918), Da/TW-448 (X62921), E/Bour (X52557), F/ICCal3 (X52080), G/UW57 (AF063199), H/ Wash (H/UW4) (X16007), I/UW12 (AF063200),J/UW36 (AF063202) and K/UW31 (AF063204) were used as reference sequences. The omp1 sequences were edited, aligned, and analysed using the MEGA6 software.

\section{Statistical analysis}

Statistical analysis was performed using the Chi square test and IBM SPSS version 20 software (IBM Corporation, Armonk, NY, USA) for establish relationship between C.trachomatis prevalence and patient's age. 


\section{Results and discussion}

A total of 419 urogenital swab specimen from symptomatic male patients were studied for $C$. trachomatis. 57 out of these 419 samples (13.6 \%) were DNA positive for C. trachomatis (Table 1). This prevalence rate of C. trachomatis in symptomatic men lies within the previously detected range in other turkish epidemiological studies (Agacfidan et al. 2001; Aslan et al. 2002; Kaleli et al. 1999). The largest proportion of cases in European countries reported in 2013 were among young people between 20 and 24 of age who accounted for $41 \%$ of cases. The second largest group was the age group of 15-19 years old accounting for $26 \%$ (ECDC 2015). However, in comparison to the age-related infection rates of European countries with the highest Chlamydia prevalence among persons with 15-24 of age, rates in our study were found to peak in the age group 20-29 $\left(x^{2}=35,587, p<0,001\right)$. The reason is suggested to be the older age at onset of sexual activity in Turkey when compared to European countries.

The genotypes of the 57 C. trachomatis-positive samples were analysed by HRMA and a total of $55 \mathrm{omp} 1$ fragments could successfully be amplified. After the HRM group analysis we discriminated 5 genotype clusters in our materials (Fig. 1) and chose two different samples from each genotypes cluster for sequencing of the omp1 gene. The five C. trachomatis genotypes were identified to be genotype $E(n=20,36.4 \%)$ as the most prevalent, followed by $\mathrm{G}(\mathrm{n}=13,23.6 \%), \mathrm{H}(\mathrm{n}=12,21.8 \%), \mathrm{D}(\mathrm{n}=9$,
$16.4 \%)$ and $\mathrm{F}(\mathrm{n}=1,1.8 \%)$ (Table 2). The predominance of genotype $\mathrm{E}$ is in line with previous studies on different patient groups (Taheri Beni et al. 2010, Ngandjio et al. 2003, Gallo Vaulet et al. 2010, Mejuto et al. 2013). Genotypes E, F and D are known to be the most prevalent genotypes circulating in heterosexual populations worldwide (Lysen et al. 2004; Taheri Beni et al. 2010; Millman et al. 2004; Ngandjio et al. 2003; Gallo Vaulet et al. 2010; Yang et al. 2010). An unusual finding of this study was the relatively high prevalence (23.6\%) of genotype $G$ in our cohort. This genotype has widely been reported for the population of men having sex with men in European and other countries (Li et al. 2011; Mejuto et al. 2013; Quint et al. 2011; Twin et al. 2011). The high genotype $G$ rates in our study might suggest a high number of men among the analyzed patients who have sex with men. Genotype $\mathrm{H}$ showed the highest frequency $(72.7 \%)$ in male patients in the age group 30-34. Interestingly, C.trachomatis genotypes J,K and I/Ia found in male patients in other reports (Lysen et al. 2004; Millman et al. 2004; Herrmann et al. 2015), were not detected in our study, which may indicate a specific geographical distribution of certain genotypes. On the other hand the number of samples included in the analysis was relatively small and genotypes with low prevalence rates might have been missed.

In conclusion, we detected five different C.trachomatis genotypes among our patients. This diversity might be associated with sexual behavior among different religious and ethnic groups living in Istanbul. We believe that this

Table 1 Prevalence of cervical C. trachomatis infection in different age groups as determined by real-time PCR

\begin{tabular}{|c|c|c|c|c|c|c|c|}
\hline Age group & $<20$ & $20-24$ & $25-29$ & $30-34$ & $35-44$ & +45 & \\
\hline$P C R+$ & $2(50 \%)$ & 17 (34 \%) & 17 (15.9\%) & 12 (16.4 \%) & $7(6.1 \%)$ & $2(2.9 \%)$ & 57 (13.6 \%) \\
\hline PCR - & $2(50 \%)$ & $33(66 \%)$ & 90 (84.1 \%) & 61 (83.6 \%) & 108 (93.9\%) & 68 (97.1 \%) & $362(86.4 \%)$ \\
\hline Total & 4 & 50 & 107 & 73 & 115 & 70 & 419 \\
\hline
\end{tabular}

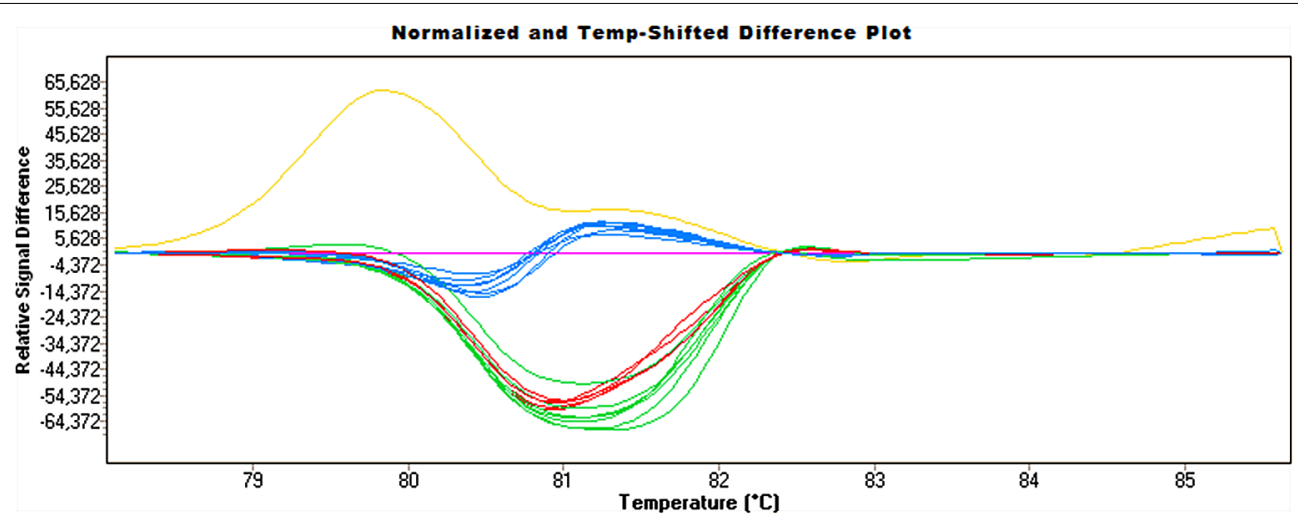

Fig. 1 Identification of five different STI-related C. trachomatis genotypes by gene scanning and genotyping analysis. Genotype specific curves were distinguishable and could be differentiated through direct visualization (green genotype E, red genotype D; blue genotype G, pink genotype H, yellow genotype F) 
Table 2 Distribution of cervical C. trachomatis genotypes in relation with age

\begin{tabular}{|c|c|c|c|c|c|c|c|}
\hline Genotypes & 15-19 & $20-24$ & $25-29$ & $30-34$ & $35-44$ & +45 & Total \\
\hline $\mathrm{D}$ & $1(50 \%)$ & $3(18.8 \%)$ & $5(29.4 \%)$ & - & - & - & 9 (16.4 \%) \\
\hline$E$ & & $6(37.5 \%)$ & $7(41.2 \%)$ & $2(18.2 \%)$ & $4(57.1 \%)$ & $1(50 \%)$ & $20(36.4 \%)$ \\
\hline $\mathrm{F}$ & - & - & - & - & 1 (14.3 \%) & & $1(1.8 \%)$ \\
\hline G & $1(50 \%)$ & $5(31.2 \%)$ & $4(23.5 \%)$ & $1(9.1 \%)$ & 1 (14.3 \%) & $1(50 \%)$ & $13(23.6 \%)$ \\
\hline $\mathrm{H}$ & - & $2(12.5 \%)$ & $1(5.9 \%)$ & $8(72.7 \%)$ & $1(14.3 \%)$ & - & $12(21.8 \%)$ \\
\hline Total & 2 & 16 & 17 & 11 & 7 & 2 & 55 \\
\hline
\end{tabular}

is the first study investigating the prevalence and distribution of genotypes of $C$. trachomatis genital infections of symptomatic men in Istanbul, Turkey.

\section{Authors' contributions}

Conceived and designed the experiments: MOK. Sample collection: AK. Performed the experiments: MOK, MD, HB. Analyzed the data: MOK, MD, AA, BA. Wrote the paper: MOK, MD, AA, BA. All authors read and approved the final manuscript.

\section{Author details}

1 Department of Medical Microbiology, Istanbul Faculty of Medicine, Istanbul University, Capa, 34093 Istanbul, Turkey. ${ }^{2}$ Department of Medical Microbiology, Cerrahpasa Faculty of Medicine, Istanbul University, Cerrahpasa, 34096 Istanbul, Turkey. ${ }^{3}$ Department of Urology, Istanbul Faculty of Medicine, Istanbul University, 34093 Istanbul, Turkey. ${ }^{4}$ Institute of Virology, University of Cologne, Fürst-Pückler-Str. 56, 50935 Cologne, Germany.

\section{Acknowledgements}

This research was sponsored by the Pera Medikal A.S. and Ekim Medikal Dis Ticaret A.S.

\section{Competing interests}

The authors declare that they have no competing interests.

\section{Ethical approval}

The study was approved by Ethics Committee of Istanbul University $(2015 / 1244)$

Received: 10 February 2016 Accepted: 23 September 2016 Published online: 04 October 2016

\section{References}

Agacfidan A, Moncada J, Aydin D, Onel M, Alp T, Isik N et al (2001) Prevalence of Chlamydia trachomatis and Neisseria gonorrhoeae in Turkey among men with urethritis. Sex Transm Dis 28(11):630-632

Aslan A, Aygün G, Polat E, Bagdatli Y (2002) Genital sistem yakınmalariyla başvuran erkek hastalarda Chlamydia trachomatis sıklığı. Infek Derg 16:23-25

European Centre for Disease Prevention and Control (ECDC) (2015) Guidance on chlamydia control in Europe. http://ecdc.europa.eu/en/publications/ Publications/chlamydia-control-europe-guidance.pdf. Accessed 5 Oct 2016

Gallo Vaulet L, Entrocassi C, Corominas Al, Rodríguez Fermepin M (2010) Distribution study of Chlamydia trachomatis genotypes in symptomatic patients in Buenos Aires, Argentina: association between genotype E and neonatal conjunctivitis. BMC Res Notes. 3:34

Herrmann B, Isaksson J, Ryberg M, Tångrot J, Saleh I, Versteeg B, Gravningen K, Bruisten S (2015) Global multilocus sequence type analysis of Chlamydia trachomatis strains from 16 countries. J Clin Microbiol 53(7):2172-2179

Kaleli I, Tuncay L, Yonguc T, Aksit F (1999) Semptomatik erkeklerde Chlamydia trachomatis tanısında idrar ve üretral örneklerin karşılaşıııılması. Gynecology Obstetrics Reproductive Medicine. 5:41-42
Li JH, Yin YP, Zheng HP, Zhong MY, Peng RR, Wang B et al (2010) A high-resolution melting analysis for genotyping urogenital Chlamydia trachomatis. Diagn Microbiol Infect Dis 68(4):366-374

Li JH, Cai YM, Yin YP, Hong FC, Shi MQ, Feng TJ et al (2011) Prevalence of anorectal Chlamydia trachomatis infection and its genotype distribution among men who have sex with men in Shenzhen, China. Jpn J Infect Dis, 64(2):143-146

Lysen M, Osterlund A, Rubin CJ, Persson T, Persson I, Herrmann B (2004) Characterization of ompA genotypes by sequence analysis of DNA from all detected cases of Chlamydia trachomatis infections during 1 year of contact tracing in a Swedish County. J Clin Microbiol 42(4):1641-1647

Manavi K (2006) A review on infection with Chlamydia trachomatis. Best Pract Res Clin Obstet Gynaecol. 20(6):941-951

Mejuto P, Boga JA, Junquera M, Torreblanca A, Leiva PS (2013) Genotyping Chlamydia trachomatis strains among men who have sex with men from a Northern Spain region: a cohort study. BMJ Open. 3(6):002330

Millman K, Black CM, Johnson RE, Stamm WE, Jones RB, Hook EW, Martin DH, Bolan G, Tavaré S, Dean D (2004) Population-based genetic and evolutionary analysis of Chlamydia trachomatis urogenital strain variation in the United States. J Bacteriol 186(8):2457-2465

Morre SA, Moes R, Van Valkengoed I, Boeke JP, van Eijk JT, Meijer CJ et al (1998) Genotyping of Chlamydia trachomatis in urine specimens will facilitate large epidemiological studies. J Clin Microbiol 36(10):3077-3078

Morre SA, Rozendaal L, van Valkengoed IG, Boeke AJ, van Voorst Vader PC, Schirm J et al (2000) Urogenital Chlamydia trachomatis serovars in men and women with a symptomatic or asymptomatic infection: an association with clinical manifestations? J Clin Microbiol 38(6):2292-2296

Ngandjio A, Clerc M, Fonkoua MC, Thonnon J, Njock F, Pouillot R, Lunel F, Bebear C, De Barbeyrac B, Bianchi A (2003) Screening of volunteer students in Yaounde (Cameroon, Central Africa) for Chlamydia trachomatis infection and genotyping of isolated C. trachomatis strains. J Clin Microbiol 41(9):4404-4407

Quint KD, Bom RJ, Quint WG, Bruisten SM, van der Loeff MF, Morre SA et al (2011) Anal infections with concomitant Chlamydia trachomatis genotypes among men who have sex with men in Amsterdam, the Netherlands. BMC Infect Dis 11:63

Taheri Beni B, Motamedi H, Ardakani MR (2010) Genotyping of the prevalent Chlamydia trachomatis strains involved in cervical infections in women in Ahvaz, Iran. J Med Microbiol. 59(Pt 9):1023-1028

Twin J, Moore EE, Garland SM, Stevens MP, Fairley CK, Donovan B et al (2011) Chlamydia trachomatis genotypes among men who have sex with men in Australia. Sex Transm Dis 38(4):279-285

WHO. Laboratory diagnosis of sexually transmitted infections, including human immunodeficiency virus. 2008:55-72. http://www.appswhoint/ iris/bitstream/10665/85343/1/9789241505840_engpdf

Yang B, Zheng HP, Feng ZQ, Xue YH, Wu XZ, Huang JM, Xue XJ, Jiang HN (2010) The prevalence and distribution of Chlamydia trachomatis genotypes among sexually transmitted disease clinic patients in Guangzhou, China, 2005-2008. Jpn J Infect Dis. 63(5):342-345

Zheng HP, Jiang LF, Fang DY, Xue YH, Wu YA, Huang JM et al (2007) Application of an oligonucleotide array assay for rapid detecting and genotyping of Chlamydia trachomatis from urogenital specimens. Diagn Microbiol Infect Dis 57(1):1-6 